Article

\title{
Railroad Buildings of Eskişehir: Challenges and Opportunities for Industrial Heritage
}

\author{
Betül Ekimci $^{\dagger}{ }^{+*}$, Feray Ergincan ${ }^{\dagger}$ and Mehmet İnceoğlu ${ }^{\dagger}$ \\ Department of Architecture, Eskişehir Technical University, Eskişehir 26155, Turkey; \\ fergincan@eskisehir.edu.tr (F.E.); mehmeti@eskisehir.edu.tr (M.İ.) \\ * Correspondence: bgekimci@eskisehir.edu.tr; Tel.: +90-2223350580 \\ + These authors contributed equally to this work.
}

Received: 30 December 2018; Accepted: 27 January 2019; Published: 30 January 2019

check for updates

\begin{abstract}
While railways are considered as a sign of development for countries, the railway structures are part of the industrial heritage of cities and comprise some of the most important urban public places. In Turkey, the Eskişehir railway buildings, constructed between 1886 and 1894, are at the west of the main railroad between the Enveriye and Eskişehir stations. They are also public places having strong resonance in the collective memory. Because of the fast development in technology, they face the threat of losing their function. Conservation of former industrial structures requires, first and foremost, identifying and documenting the distinctive features that makes them cultural heritage sites. It is a shared responsibility between public institutions and sectors to identify and protect the distinguishing features of industrial heritage sites. With this awareness, at the Anadolu University Architecture Department, integrated student work focused on the Railroad Roundhouse-built in 1896 - and Staff Housing Quarters - built in the early 20th century - which are part of this district and embody a series of urban problems, was carried out over four academic semesters. This study focuses on historic railway buildings in the Eskişehir railway district that is known for its urban problems. An exhibition combining these student works was opened at the Railcar Repair Facility on 16 November 2017. This exhibition showcased the student involvement in history of Eskişehir and increased public awareness of cultural heritage.
\end{abstract}

Keywords: industrial heritage; architectural conservation; railway buildings; Eskişehir; Turkey

\section{Introduction}

Transformation of former industrial sites in cities for reutilization is among the current topics of architectural conservation. Industrial heritage conveys archaeological evidence of past industrial technology and processes, engineering, architecture, and town planning. It also includes the memories and social life of workers and their communities. Due to fast development in technology, many former industrial structures and premises have been abandoned. Though some of them had been constructed out of town, they stayed inside the town centre due to the enlargement of towns. This aspect, which poses a general threat to the conservation of industrial heritage, brings about problems of destruction, renovation, and rant-based utilization. Making a successful adaptive reuse project is an important question for the maintaining of these places, which are left without function and under the pressure of urban development. In Europe and America, since the mid-1970s, the practice of transformation of industrial heritage has been given greater attention gradually. Many successful projects of transformation and reuse have been carried out by the formulation of charters, which have all played a guiding and promoting role in the transformation of industrial heritage, as listed in Table 1. 
Table 1. The main international conventions on the protection and renovation of industrial heritage sites (source: correspondence author).

\begin{tabular}{clcc}
\hline Convention Name & Time & Publishing Agency & Place \\
\hline Athens Charter & 1933 & CIAM & Athens \\
Venice Charter & 1964 & ICOM & Venice \\
Nairobi Recommendation & 1976 & UNESCO & Nairobi \\
Machu Picchu Charter & 1977 & CIAM & Lima \\
Washington Charter & 1987 & ICOMOS & Washington \\
Nizhny Tagil Charter & 2003 & TICCIH & Nizhny Tagil \\
Dublin Principles & 2011 & ICOMOS & Paris \\
Taipei Declaration & 2012 & TICCIH & Taipei \\
\hline
\end{tabular}

\section{Administrative Framework for the Protection of Industrial Heritage}

With the opinions and implementations shaped in European countries such as England, France, the Netherlands, and Germany since the mid-20th century, industrial heritage concepts have been incorporated within the bodies of international conservation organizations such as ICOMOS, DOCOMOMO, and especially, TICCIH.

In the 19th session of the Barcelona International Building Association (UIA) in 1996, it was pointed out explicitly that protection, management, and regeneration is needed in the abandoned areas in the city, such as the industrial area, railways area, docks, etc. In the 2003 TICCIH Congress in Russia, the "Nizhny Tagil Charter" made a clear provision to industrial heritage, which was namely the definition of value and importance of identification, record-keeping, and research of the industrial heritage [1]. According to Dublin Principles, adopted by the 17th ICOMOS General Assembly on 28 November 2011 (Joint ICOMOS-TICCIH), the Principles for the Conservation of Industrial Heritage Sites, Structures, Areas, and Landscapes are as follows:

(1) Definition: The industrial heritage consists of sites, structures, complexes, areas, and landscapes as well as the related machinery, objects, or documents that provide evidence of past or ongoing industrial processes of production, the extraction of raw materials, their transformation into goods, and the related energy and transport infrastructures. Industrial heritage reflects the profound connection between the cultural and natural environment, as industrial processes-whether ancient or modern-depend on natural sources of raw materials, energy, and transportation networks to produce and distribute products to broader markets. It includes both material assets-immovable and movable - and intangible dimensions such as technical know-how, the organization of work and workers, and the complex social and cultural legacy that shaped the life of communities and brought major organizational changes to entire societies and the world in general.

(2) Industrial heritage sites are very diversified in terms of their purpose, design, and evolution over time. Many are representative of processes and technologies as well as regional or historical conditions, while others constitute outstanding achievements of global influence. Others are complexes and multiple-site operations or systems whose many components are interdependent, with different technologies and historical periods frequently present. The significance and value of industrial heritage is intrinsic to the structures or sites themselves, their material fabric, components, machinery, and setting, expressed in the industrial landscape, in written documentation, and also in the intangible records contained in memories, arts, and customs [2].

Though Turkey is party to the decisions of these institutions, she has not yet incorporated the industrial heritage concept into her domestic legislation. Industrial heritage in Turkey is a new concept that started to come into existence in the1990s. Industrial heritage structures, which were established with design decisions intended for functional and convenient usage besides heavy engineering knowledge, have changed the features of the city, and have become a landmark by gaining artistic value that is called the "factory" aesthetic today. With their development value, relative art 
value, and utilization value, as put forward by Alois Riegl, they have become a cultural presence based on technology $[3,4]$.

Currently, there are 155 inventoried industrial and commercial buildings in Eskişehir, as highlighted in Figure 1 [5]. Due to the urban sprawl, many industrial buildings which were formerly at the "edge" (or even suburban) areas are increasingly becoming surrounded by the expanding urban area. In the last two decades, survey analysis, research, record-keeping, and some reuse projects were carried out for the industrial sites in Eskişehir [6,7]. Some of the structures in the area were registered according to the 1/5000 Master Plan, approved in 26 July 2002 and revisioned in 20 October 2003 and 1/1000 Development Plan for the factory area approved in 11 December 2003 [8,9]. Besides, among these, there are those, such as the Railway Station Building (İstasyon Binasi), that were registered with the status of a memorial structure/building; 'single structure' registration decisions were taken for industrial facilities occupying a wide area, parcel layouts were divided with the purpose of "utilization for public interest", and approaches which take into account production accessories, structure appurtenances, and environmental and town landscapes of the sites were not followed in reutilization applications. For example, the Espark Shopping Center, put into service in 2007, was built on the site of the destroyed Kurt Briquetting Plant, established in 1927, and the brick-laid chimney of the plant was dismantled from its original place and reinstalled into another place in accordance with the layout of the shopping center (see Figure 2).

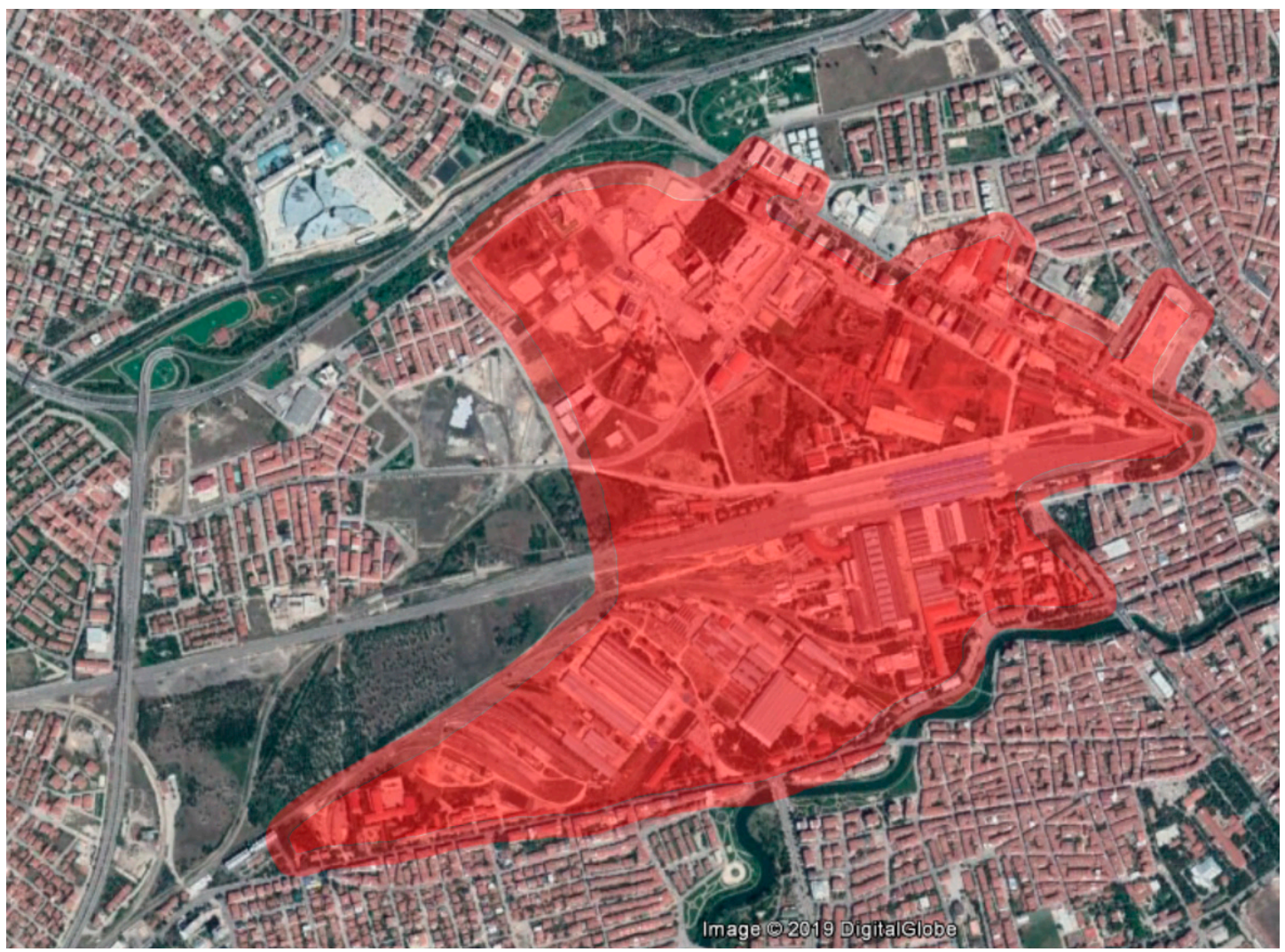

Figure 1. General location of the industrial area which is surrounded by the Turkish State Railways (TCDD) and Tülomsaş Establishment in Eskişehir (produced after the 2019 aerial image from Google Earth, accessed on 15 January 2019). 


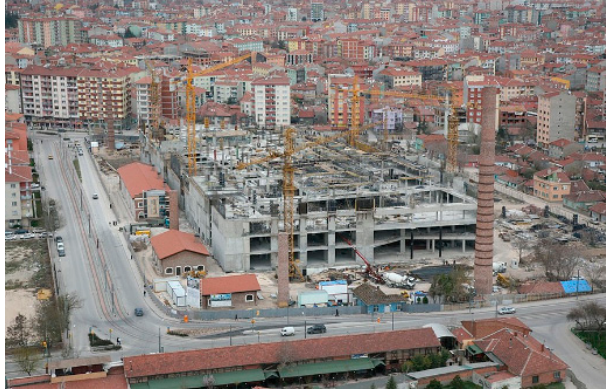

a

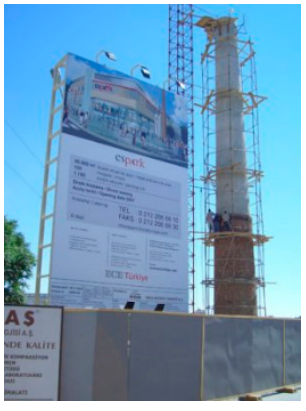

$\mathrm{b}$

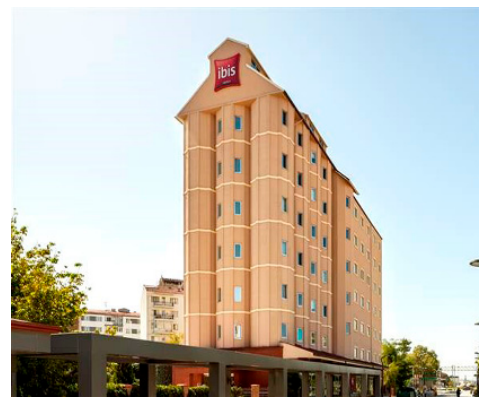

C

Figure 2. (a)Espark Shopping Center (former brick and tile factory), during the construction, 2007 [10]. (b)Reconstruction of the factory chimney, (c) İbis Hotel.

Only the facade of the Eskişehir TMO Granary, which was built in 1934 by prefabricated concrete system, was preserved when it was transformed into the İbis Hotel. After the internal space was rearranged, it was no longer possible to understand the original functioning scheme from the remaining traces.

On the other hand, since there is no detailed inventory study on many industrial structures of the town, and more importantly, since mechanisms protecting the significance of the internal space have not yet been developed, machine hardware and equipment disappear irreversibly. In structures belonging to private or public organizations, authorities either dismantle and take technical and social fittings, machines being priority, to be used in new service buildings or primarily consider theirs crap value. Thus, the internal space's significance, which displays the production process, labor, and technology development of this heritage, is being obliterated.

One of the central problems in the preservation of industrial heritage is the lack of effective dialogue taking place between institutions and stakeholders regarding on private property rights; urban land development and the demand for new construction, legal, and administrative processes; increase in public demands; shortage of economic resources; etc. In the solution of such problems, the appropriate conditions are not always realized, and thus structuring channels of communication between stakeholders and decision-makers can fail. At this stage, industrial assets that need to be protected lose their valuable constituent parts. If the establishment of the dialogue channels between stakeholders and policy-makers, which enables long-term preservation of the idle industry heritage, is prolonged, the valuable elements of the heritage are rapidly lost. On the other hand, cultural heritage management arrangements are inadequate to establish a collaborative relationship between organizations for the joint decisions on resolution plans.

If the lack of dialogue between stakeholders becomes a growing problem starting from individuals, local, small-scale, short-term, multicultural activities help in achieving long-term sustainable conservation goals. Exhibiting is generally seen as a communication tool and a way for individuals to communicate with the environment. In this context, an exhibition was organized by taking an example from the 'temporary uses' of derelict industrial spaces in contemporary art projects [11]. In the next step, the challenges and opportunities in revealing the potential of local actors to participate in the endangered cultural heritage have been evaluated.

\section{Materials and Methods}

In recent years, in Europe and the USA, a new multidisciplinary trend which uses abandoned buildings as exhibition spaces or art studios has emerged. Though such preferences emerged, first of all, as a result of the flexible usage feature of wide and spacious locations with convenient prices, these experiences have had very beneficial outcomes for both artists and abandoned industrial heritage sites [12,13]. In these activities, idle industrial structures and areas are presented as impressive visual features forcing the limits of arts and becoming etched in the mind. These artistic trends, which 
transform these spaces into art workshops and indulge in its empty, lonely, ruined, and sad atmosphere, at the same time, helps for confrontation opportunity by reintroducing these spaces to society. Bringing together multidisciplinary artists, a wide range of activities, from installation to performance and from photographing to exhibition, can provide these long-idle spaces with a new feature that ensures the sustainability of a collective memory. In this study, taking example of the temporary usage model of abandoned industrial structures by contemporary art applications, a new project for the exhibition has been conducted in which local actors and stakeholders are brought together. The study topic is chosen from Eskişehir. Eskişehir is one of the leading cities in Turkey's industrialization. That the Berlin-Baghdad railroad passed through Eskişehir had a great impact on the town's industry and city planning. In the town's development, the railroad and its structures became critical components. Eskişehir Railroad Station District (TCDD), the topic of the study, and the Railroad Staff Housing Quarters are located in the vicinity of the central station in the town centre.

The buildings constructed between 1886 and 1894, situated at the west of the main railroad between Enveriye and Eskişehir, consist of railroad buildings such as a large stone-made factory together with a locomotive depot (currently the Roundhouse Railway Workshop), commodity depot, dormitories for mechanics and janitors, ticket booth, and lodgings [14]. At the north of the railroad are the Roundhouse Railway Workshop and associated buildings together with single-store gardened lodging buildings.

Furthermore, the area in close vicinity of the Railroad Station area, associated with complex commercial and industrial functions, established with the initiative of private sectors in the last quarter of the 19th century, and also involving buildings belonging to New Turkey's first construction material company, Kılı̨̧oğlu Tile and Brick Factory, is named the "Eskişehir Factories Zone". This area, where both state and private industry coexisted, contributed significantly in the industry of Eskişehir and the country and occupies an important space in the town memory and town planning.

The majority of the railroad buildings used until recent years were abandoned after the construction of the high-speed train and the transfer of the railcar repair facility to its new place. These locations, closed to the public and deserted due to staying dysfunctional and being neglected, are still strong representatives of the town's industrial heritage. Inventory record of only a couple of structures within the railroad premises, which is important for Eskişehir and which changed the town's features and culture of life, exists today. Turkish cultural protection laws do not have a specific subcategory for an "industrial heritage site"; as such, a site can only be categorized as a "protected site". For example, one of the centerpieces of the site, the greenhouse, was recently burnt to the ground as a result of the illicit activities of substance abusers.

Conservation of structures requires, first and foremost, identifying and documenting the distinctive features that makes them cultural heritage sites. Conservation of something valuable requires, first and foremost, being respectful of that value, making it necessary to clearly identify its constituent parts. A few aspects need special attention in cataloguing industrial heritage sites. The cultural inventory of the site needs to be prepared, and a road map must be drawn in a timely manner, before the integrity of the site deteriorates due to the collapse of structures, removal of old machinery and installations, disposal of written and visual documents, and death of knowledge able individuals from the era. It is a shared responsibility between public institutions and sectors to identify and protect the distinguishing features of industrial heritage sites.

With this awareness, at the Anadolu University Architecture Department, integrated student work focused on the Roundhouse Railway Workshop (built in 1896) and Staff Housing Quarters (built in the early 20th century), as part of this district which embodies a series of urban problems, was carried out over four academic semesters. A series of courses, the 2015-2016 Spring Semester MIM320 (A-C), MIM330 (A-C) Architectural Conservation II, and 2016-2017 Fall Semester KOR523 Conservation Project I, focused on one district which is known for its urban problems. The courses were aimed at cataloguing the aforementioned structures by guiding students to prepare detailed site plans to scale, to identify heritage aspects, and to prepare written and visual documentation. 
Another series of courses, 2016-2017 Fall MIM313 Architectural Design Studio V (A), VII (C), and 2016-2017 Spring MiM118 Basic Design II (A), focused on the Central Station district including the Roundhouse Railway Workshop. These courses aimed at studying the impact of the public spaces on the public identity and collective memory. These studies helped prepare proposals for the future of the Roundhouse Railway Workshop and its environment.

Finally, an exhibition combining these student works was organized (see Figure 3). The works prepared for this exhibition consist of three stages (courses):

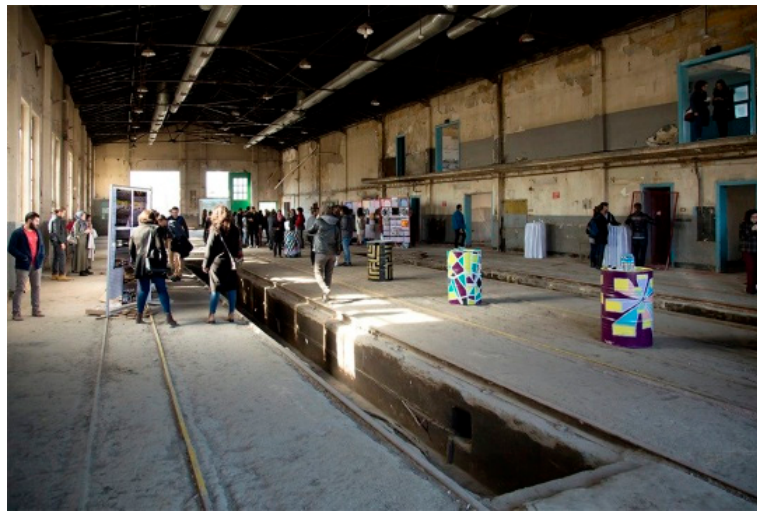

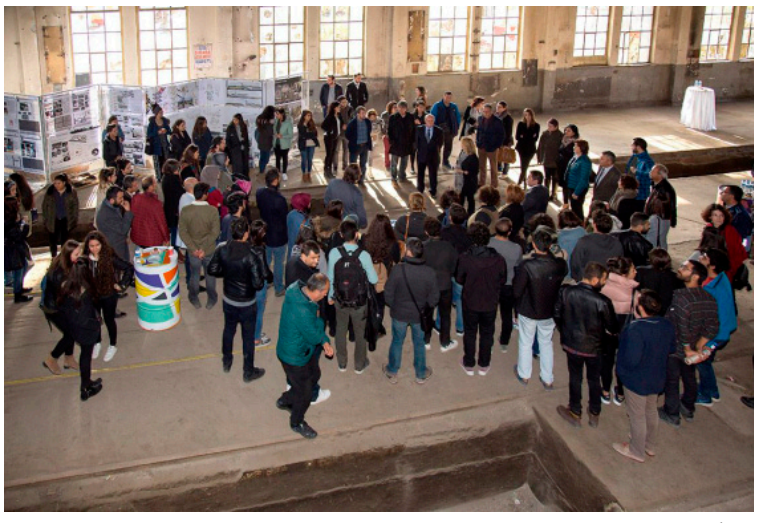

b

Figure 3. $(\mathbf{a}, \mathbf{b})$ : During the exhibition.

\subsection{Architectural Documentation Studies}

During the 2015-16 spring term, two courses, MİM320 Architectural Conservation II (A-C) and MiM330 Architectural Conservation II (A-C), were offered to document he Roundhouse Railway Workshop and staff accommodation buildings in the campus.

The foundation of the Eskişehir Central Station Campus was laid in the late 19th century, during the Ottoman Empire era, when Eskişehir became part of the Baghdad railway project. The site started to develop as more buildings were built as needed. The original buildings show the influences of the European industrial revolution and the architectural trends of the era. After the collapse of the Ottoman Empire, the site continued to develop under the rule of the Turkish Republic.

The campus consists of several buildings that were added in several stages. The most important buildings are the main station, locomotive factory, technical support quarters, staff accommodation, and hospital, as well as social and cultural centres.

During the establishment of the Turkish Republic, the government policies led the way to adopt modern architecture and urban living by building factories and workshops surrounded by urban quarters together with social and cultural centres. Eskişehir Central Station Campus is a fine example of this policy. The campus served as a centre for industrial development and as a college to educate personnel, as well as an influence on the urban life and architecture, with its modern buildings and cultural centre.

The field study was completed in five weeks during a four-hour-long class each week. A group of 40 students was assigned to document the Roundhouse Railway Workshop, and another group of 29 students was assigned to document Staff Accommodation Buildings (see Figure 4).

The documentation studies started with literature research on the site and buildings. In the field, the buildings were photographed, the sketches were drawn by hand, and measurements (straight and diagonal) were taken using both a laser distance measure and a tape measure. Scaled drawings were produced using these measurements. The students also investigated the construction technologies and the details, as well as the damages and additions/modification to the original buildings. 
For final evaluation, the students were asked to hand in a study report; picture album; 1/200 site plan; $1 / 50$ plan with scale, sections, and elevations; $1 / 20,1 / 10$, and 1/5 detail drawings; damage analysis; material analysis; and addition/alteration analysis.

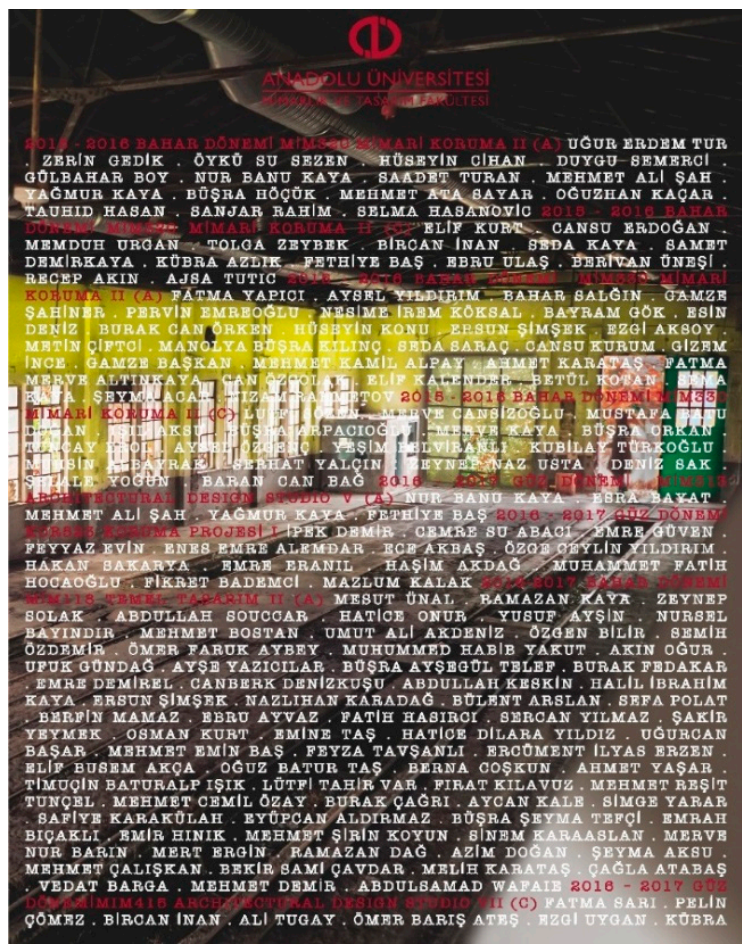

Figure 4. Exhibition poster: names of the students who participated in the documentation.

\subsection{Basic Design Studio: Railway Stories}

"Train journeys have a sense of loneliness and sadness. The journey can sometimes mean separation, an escape. A passenger goes to a place he does not know, another to his longing for his home. No matter what kind of trip you take, you often go through a myriad of emotions. Whatever the way, the time on the road is the time between strangers. It is a time to think. It is a time of beginnings".

In the railway stories given to students, various moods and journeys are told by the famous writers. All the stories have characteristic internal structures based on the power of observation. The external environment and the feelings created by the story have special characteristics and differences. In other words, each story has a unique pattern. The students were expected to make a superficial tissue study that outlined this objective effect and texture. The color range that could be used in the study was determined, an example of which is shown in Figure 5. Color selection and the number of colors was optional.

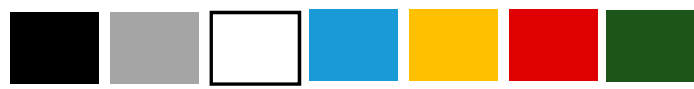

Figure 5. The color scheme, used in the basic design study.

\subsection{Architectural Design Studio}

The Roundhouse Railway Workshop is a heritage precinct adjacent to another railway building of Eskişehir (see Figures 6 and 7). The Roundhouse Railway Workshop was established in 1886 to service steam locomotives. Turkey's first locomotive was manufactured and maintained onsite until the 2000s. It is significant for its demonstration of the development of railway policy, engineering, and operations over 120 years. The Roundhouse also played an important role in part of the industrial history of Turkey. 


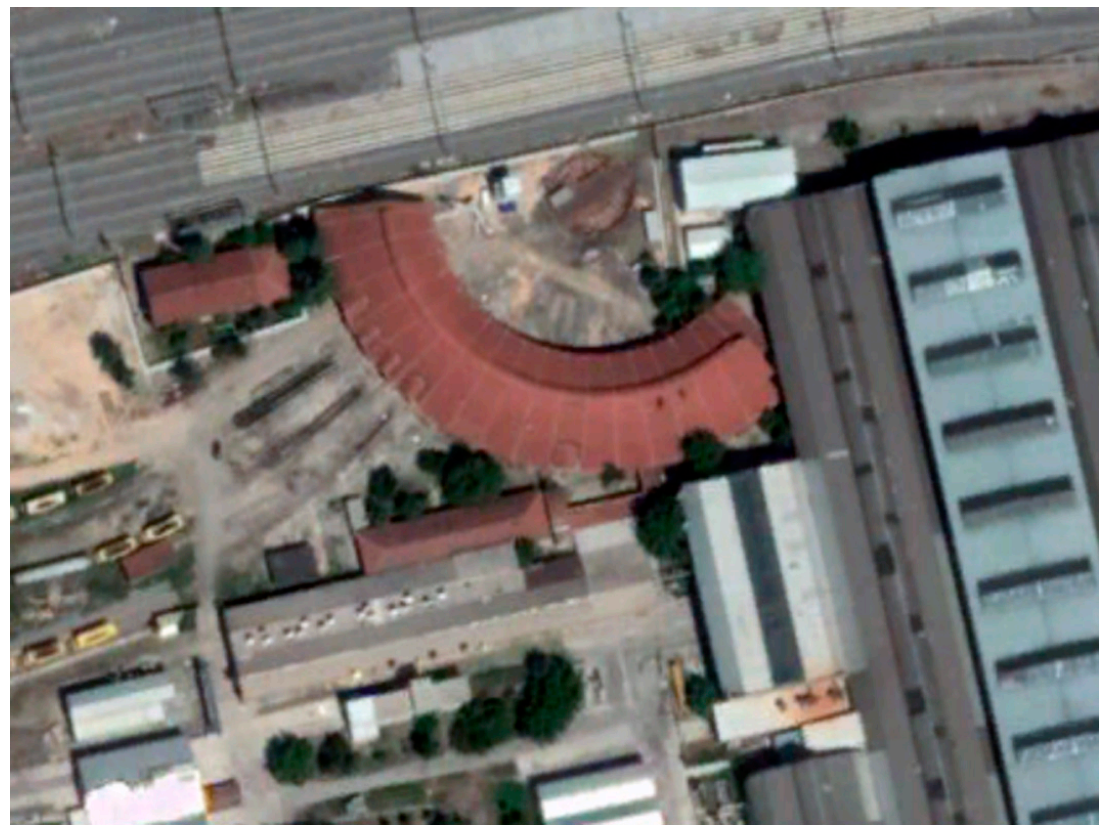

Figure 6. Aerial view from the Roundhouse Railway Workshop.
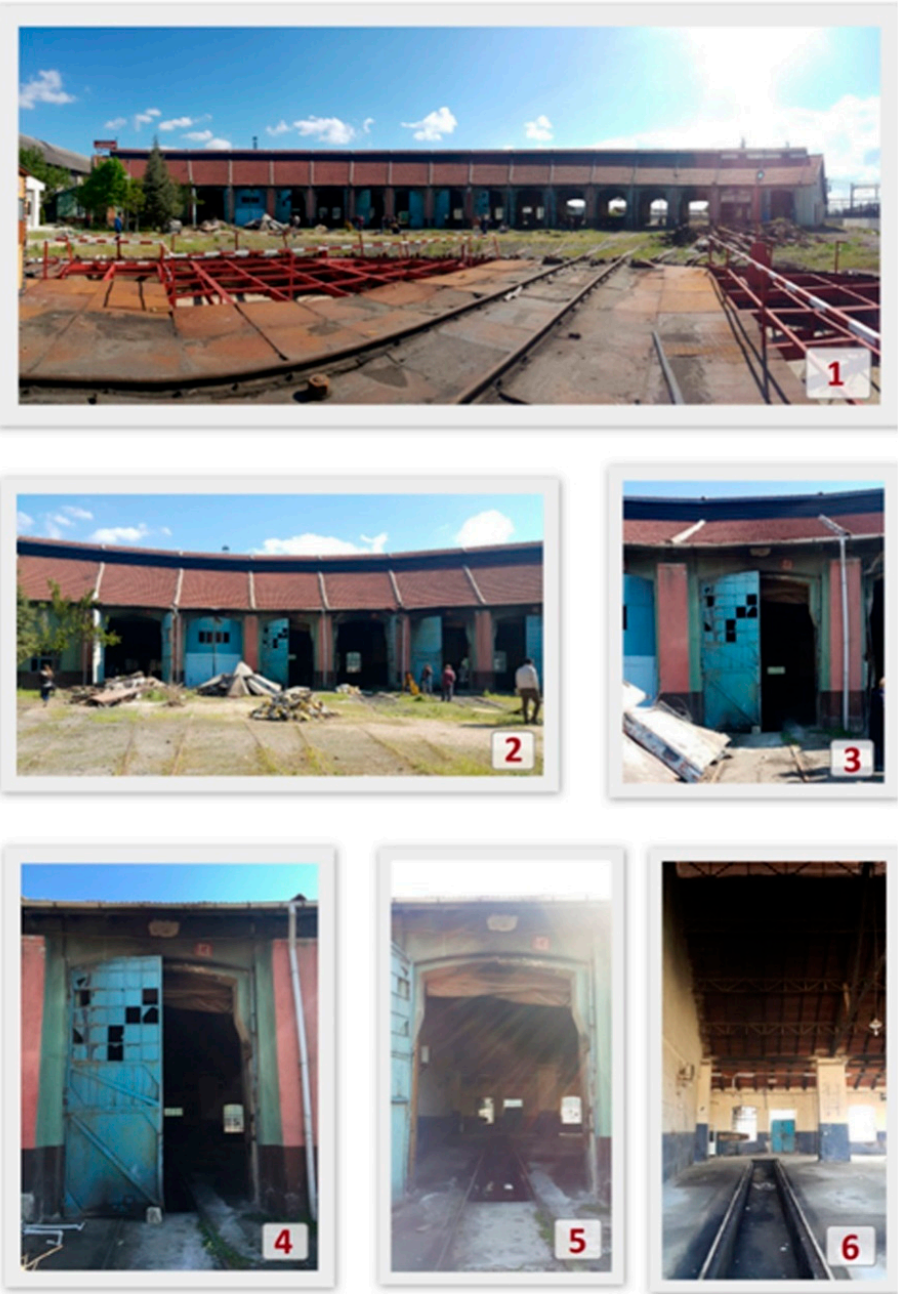

Figure 7. (1,2): North façade of the Roundhouse Railway Workshop, (3-5): gate doors of the sections, (6) view from inside of the Workshop. 
This study proposes a project to make use of the Roundhouse Railway Workshop so as to protect and improve its natural and cultural value. Architectural studio practices, including a technical-focused trip through some industrial historical sites from Eskişehir to İstanbul by train and research presentations related with railway culture in Turkey, ensured an integrated design process, including heritage conservation and design principles. First of all, the natural and physical value of the Roundhouse Railway Workshop were analyzed by means of a field study and a comprehensive literature review. Following the identification of the physical and social values and problems, some recommendations for the reuse of the Roundhouse Railway Workshop were proposed. The industrial identity of the area, the demands of the residents, and the social and economic structure of the area were considered when the functions for reuse were specified.

The adaptive reuse proposals were framed by three principal concerns: working with the industrial nature of the building and precinct, the probable location of the new fast railway station, and fully integrating design principles expressing these as 'loose fit' solutions for the public needs. Students' proposals ranged from cultural, hospitality, and educational facilities to recreational facilities in the abandoned railway building and its vicinity.

\section{Results}

Before the exhibition, two things were on our minds: firstly, how an exhibition can make an abandoned industrial heritage site visible, and secondly, how vital it is to bring together local authorities and inhabitants to discuss the proper reuse of our industrial heritage. The 24-meter-high, open space of the Railcar Repair Workshop offered a large, robust, light-filled space for the exhibition.

An exhibition featuring the student projects was opened on 16 November 2017 in the now defunct Railcar Repair Workshop located in the campus. Installations bringing together different applications such as photography, writing, collage, technical drawing, modeling, and video were exhibited for the first time in Eskişehir. The exhibition mainly consisted of three parts.

At the introductory section of the exhibition, posters exploring the history of industrial sites of Eskişehir prepared by lecturers and a documentary video demonstration about the Eskişehir Railway Campus took place. The subsequent section consisted of sketches and drawings of architectural documentation of the Locomotive Repair Workshop (the Roundhouse Railway Workshop) and staff accommodation buildings, as detailed below.

\subsection{Locomotive Repair Workshop (the Roundhouse Railway Workshop)}

The first project was the documentation of the Roundhouse Railway Workshop in an abandoned quarry in Turkish State Railways. The Roundhouse Railway Workshop is located to the west of the main station building and on the south side of the railroad tracks. The building is in an arc shape (see Figure 8) and is divided into several workshops, each of which can handle a locomotive. In the centre of the arc, there is a steel platform capable of rotating the locomotive. Railroad tracks radiated from this centre into the repair workshops, even though some tracks have been removed.

The foundation of the building is stone and the walls are brick (Figure 9). The construction is masonry with a hipped roof with steel trusses covered with tiles on wood underlay. A skylight at the top continues along the roof (Figure 10).

Both sides of the workshops have large and wide doors to allow easy access for the locomotives. The doors are double-winged and constructed of steel with a wood covering. Some doors have been removed or replaced. 


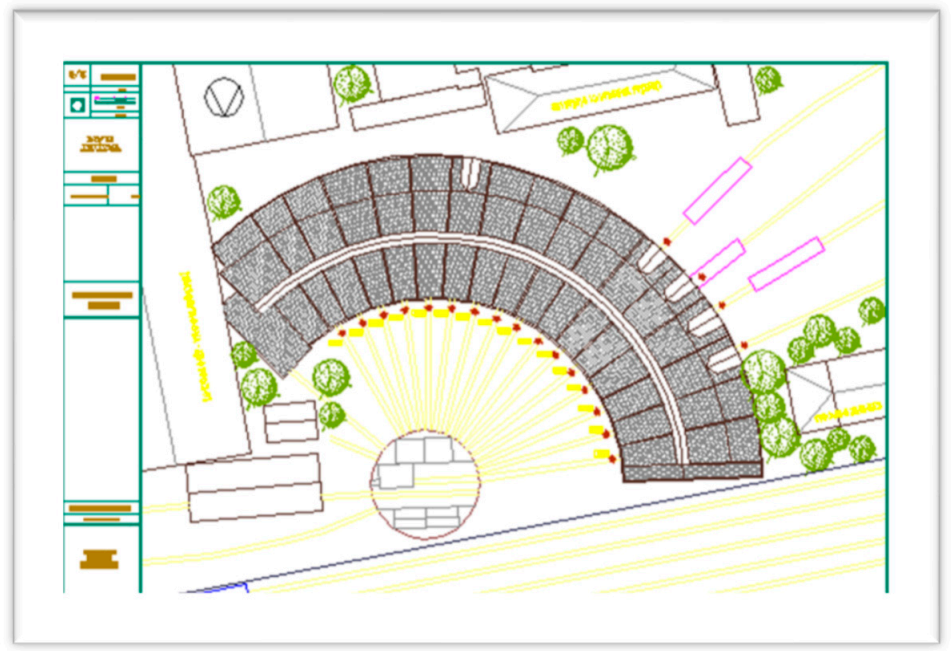

Figure 8. Site plan of the locomotive repair workshop (the Roundhouse Railway Workshop).

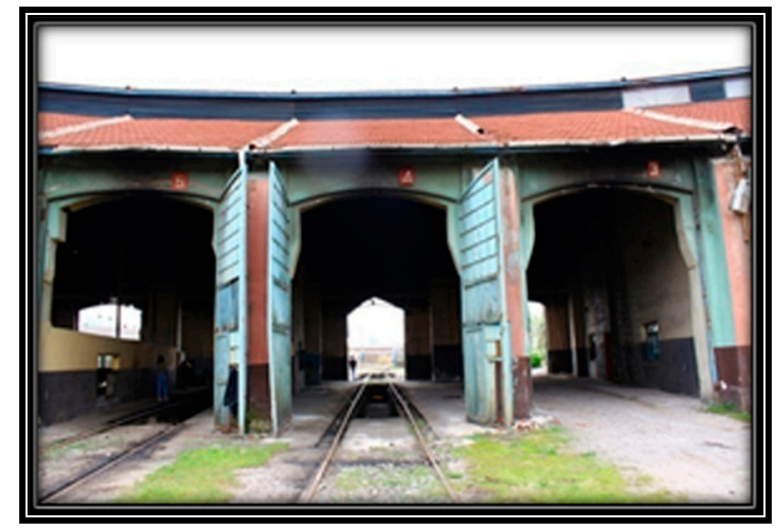

Figure 9. The Roundhouse Railway Workshop; northern entrance.

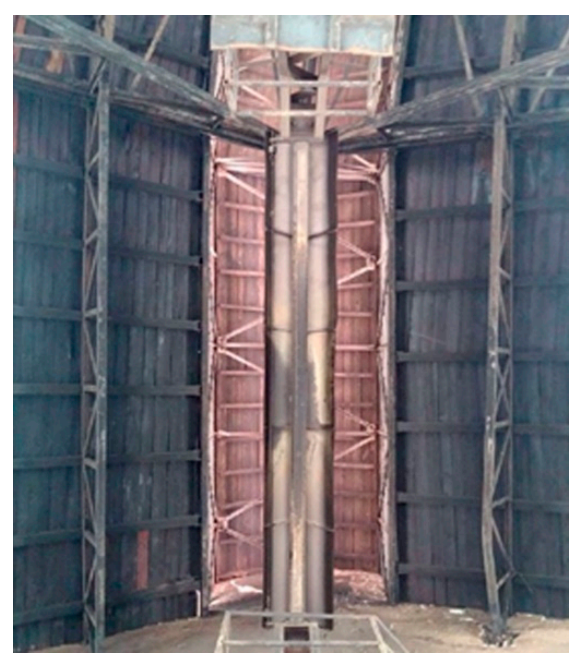

Figure 10. Roof construction of the Roundhouse Railway Workshop.

The depth of the workshops is enough to contain a locomotive $(24.30 \mathrm{~m})$. There is a pit under the interior tracks (2.30m deep) for the repair crew to work under the locomotive. In some workshops, these pits are filled. Large weight-carrying brick columns separate the workshops at the north and 
south sides (Figure 11). These columns determine the width of the workshops. The distance between columns is $10.30 \mathrm{~m}$ at the south side and $8.10 \mathrm{~m}$ at the north side.

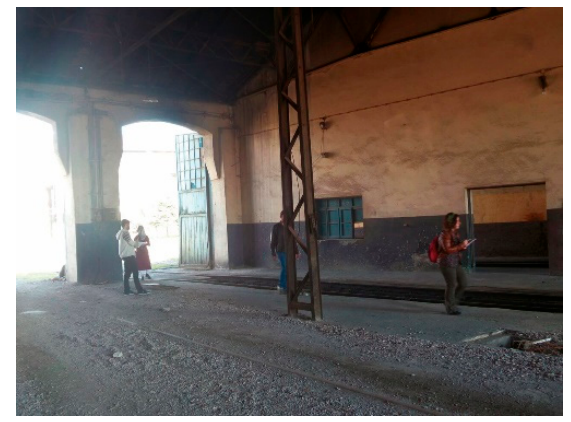

a

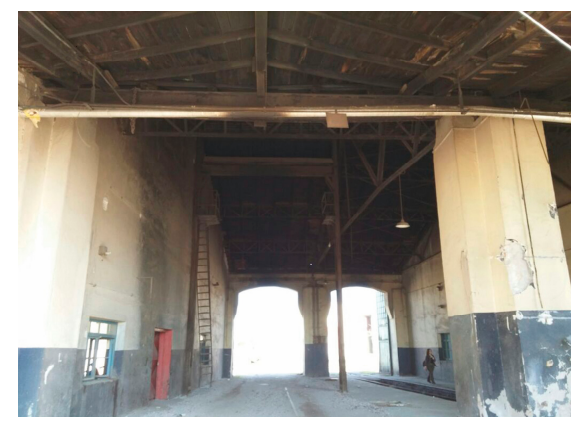

b

Figure 11. $(\mathbf{a}, \mathbf{b})$ : Interior view of the Roundhouse Railway Workshop.

The Roundhouse Railway Workshop has an important place in the history of the railways as well as the city's collective memory, even though the workshop is no longer functional. Because of lack of attention, some technical and architectural elements have either been removed or replaced. The building is structurally intact, but has sustained some damage. It is very important to keep this building for the future generations as part of our industrial heritage and for Eskişehir's collective memory.

\subsection{Staff Accommodation Buildings}

The physical and social environment of the state-owned factories, built in the early years of the Turkish Republic, provided a model to establish modern cities. The State Railway's Eskişehir Central Station Campus is an example of the government's vision for urban planning. The campus was later expanded in several stages by adding staff accommodation, complete with cultural centers, to house the increasing number of employees and their families. The majority of these buildings reside on the southern side of the railroad tracks and have a very strong connection to the downtown area.

There is another accommodation site on the northern side of the railroad tracks (Figure 12). This site has five buildings. Each building consists of two semidetached twin units. These buildings are part of the Eskişehir Central Station Campus and are included in this study. This site has a weaker connection to the downtown because of the divide caused by the railroad tracks. The buildings are positioned parallel to the railroad. To the west of the buildings lies the railcar repair workshop where the exhibition took place.

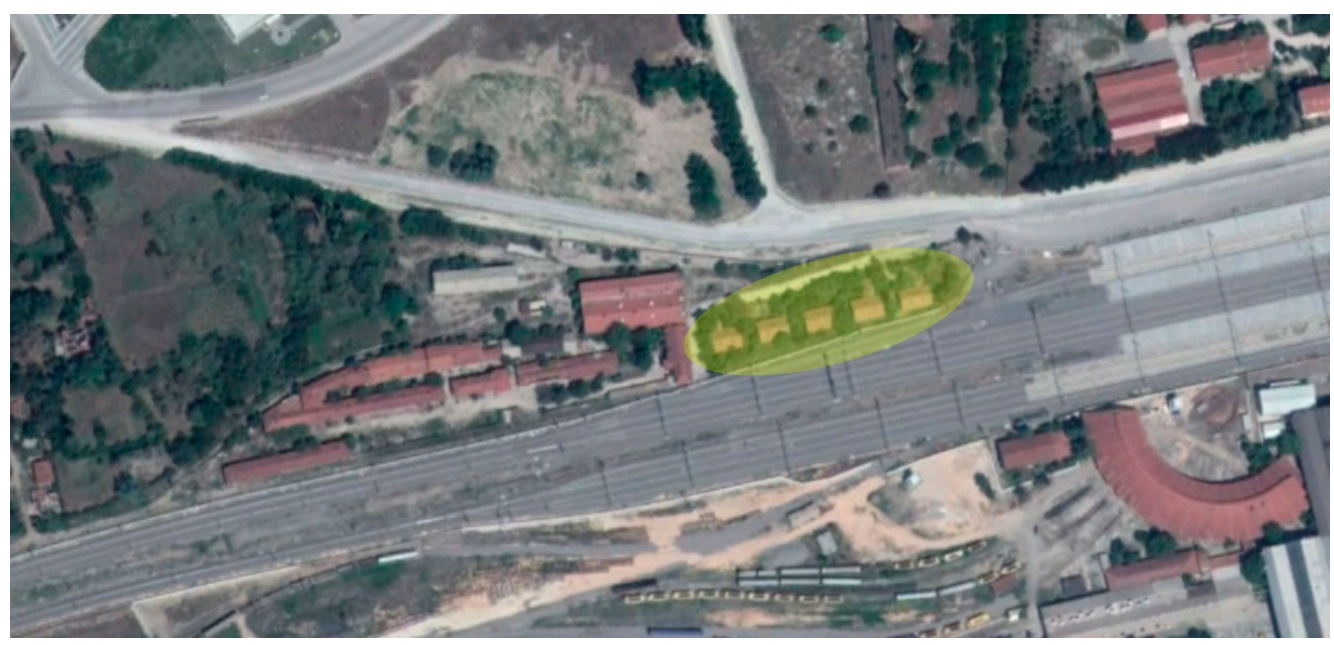

Figure 12. Staff accommodation; aerial photo. 
The first step in the architectural documentation of the staff accommodation was the sketch drawings and measurements (Figure 13).

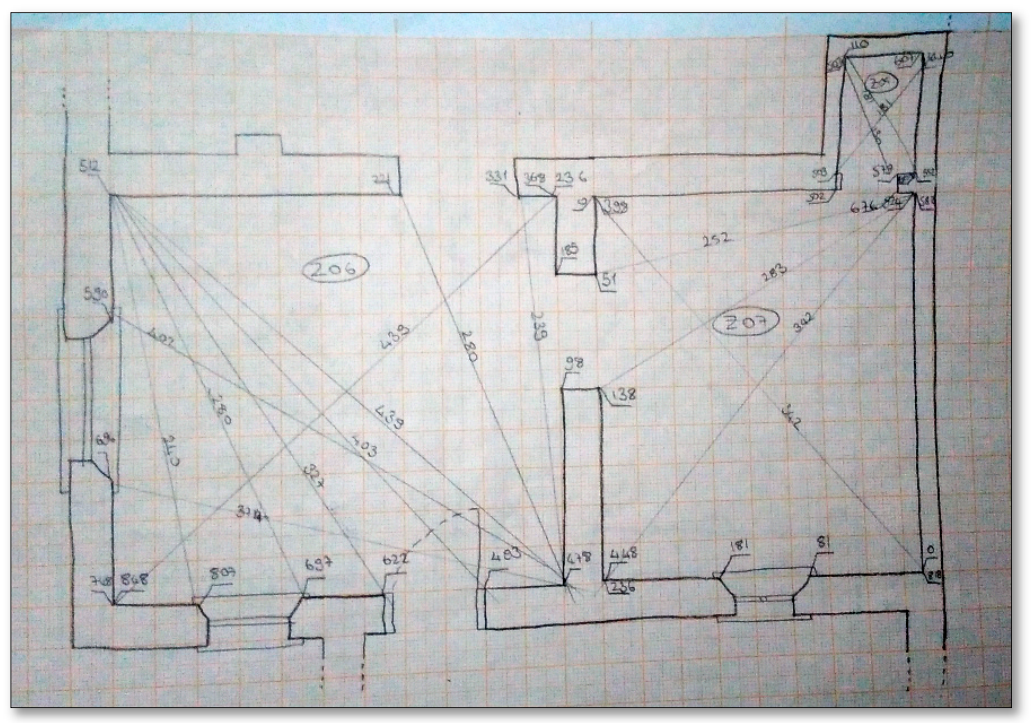

Figure 13. Plan sketch with measurements of the staff accommodation.

A total of ten units were built as five semidetached twin building. Each building has a single story and has its own yard. We could not determine whether the buildings were intended for the blue- or white-collar workers. The plan layout suggests that the units were designed to meet the minimal needs of a nuclear family. Each unit is about $60 \mathrm{~m}^{2}$ in size. The entrance is protected by a small hallway. The unit consists of a living room and two bedrooms plus a kitchen, bathroom, and washroom. The bedrooms face south; the hallway, living room, and kitchen face north. The bathroom and washroom are in the centre of the building (Figure 14).

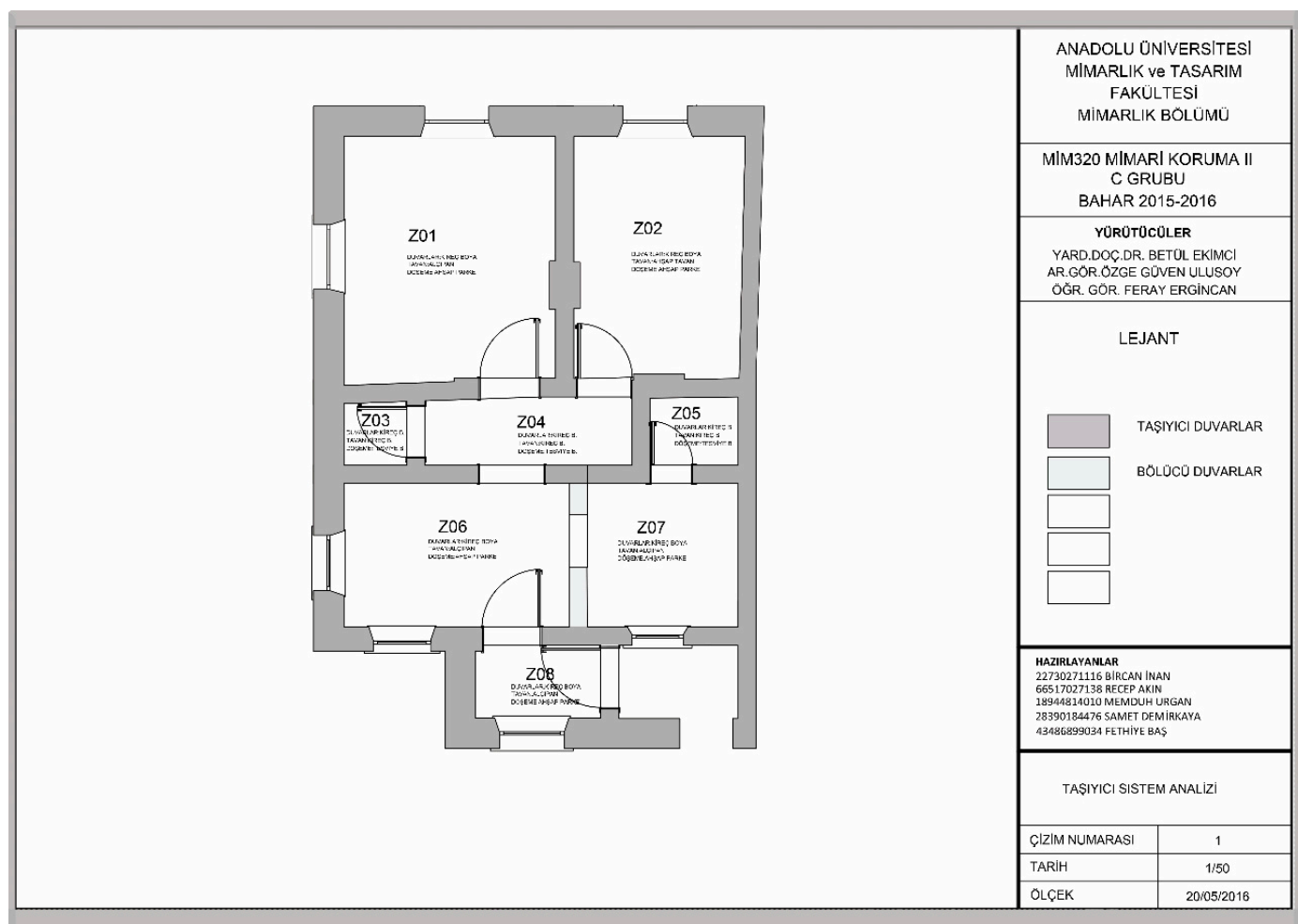

Figure 14. Planof the staff accommodation. 
The units were built using masonry construction. The foundation is stone and the walls are brick. The roof was built using wooden trusses and is covered with tiles. The floors are wood veneer in the rooms and concrete in the other areas. The windows are in the form of small gaps. The exterior of the windows are protected by horizontal iron bars. A molding goes around the exterior walls and tracks the window casings at the top (Figure 15).
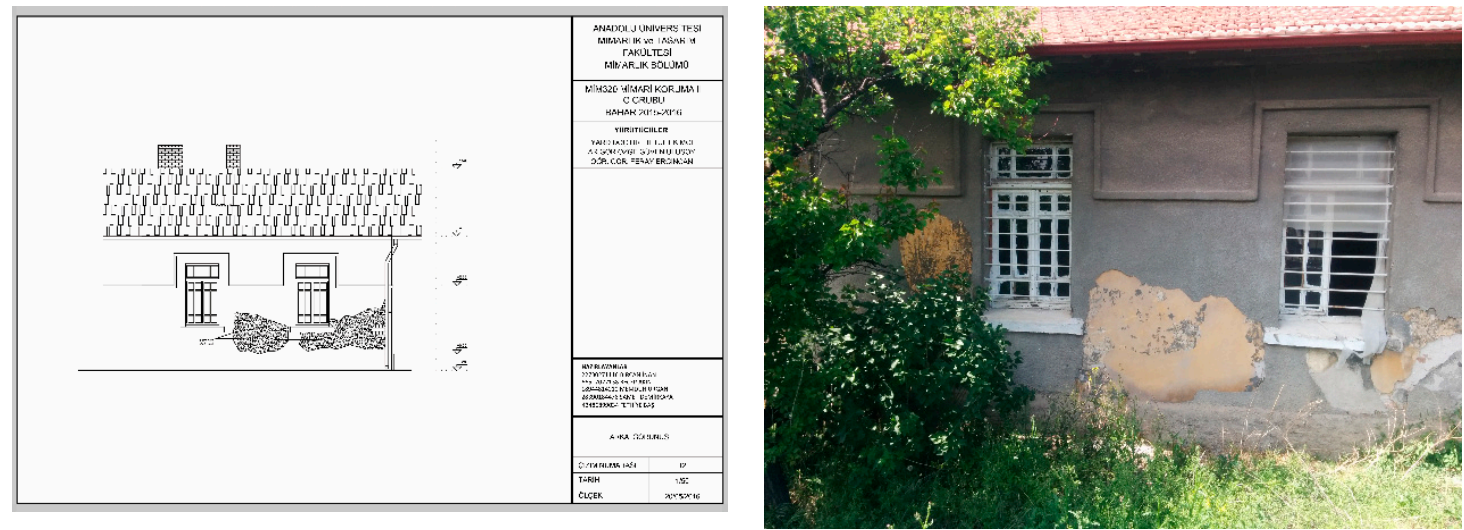

Figure 15. Southern façade drawing(left) and photo(right).

Influences of early 20th century architecture can be observed in the buildings, even though the exact date of the construction remains unknown. Minimal plan drawing, façade organization, and mass relations reveal these architectural influences.

Most of these buildings are abandoned at present. There are a few damages in the buildings due to lack of maintenance, but the buildings are structurally intact. A few minor additions and alterations to the buildings are observed, but these changes are not significant enough to change the overall building integrity.

The second part of the exhibition consists of design studio proposals for the future of the Roundhouse Railway Workshop and its environment.

Industrial plants have been affected by the changes of technologies and moved to another region, and the Roundhouse Railway Workshop was closed. Inactive industrial facilities have begun to be damaged. No studies about conserving and reusing this area have not been done until now. The Roundhouse Railway Workshop is in danger of some adverse factors, such as new city regulations, profit pressure, and physical deformation. In this study, some functional proposals for the reuse of this industrial area have been suggested. The program for the building was designed by each students, but must have included the cultural space. Moreover, an education complex, due to the recently increasing number of education complexes and potential young population, accommodation units to host visitors, and also restaurants and cafes, which locals and visitors can use were suggested to be developed in this area.

Results showed that when careful planning considering the location of existing historical buildings in the context of new enclosed spaces is carried out, it ensures the sustainable treatment of heritage with a contemporary manner and successful environmental design (Figure 16). It is determined in this study that the physical and social values of the Roundhouse Railway Workshop can be conserved and sustained. 


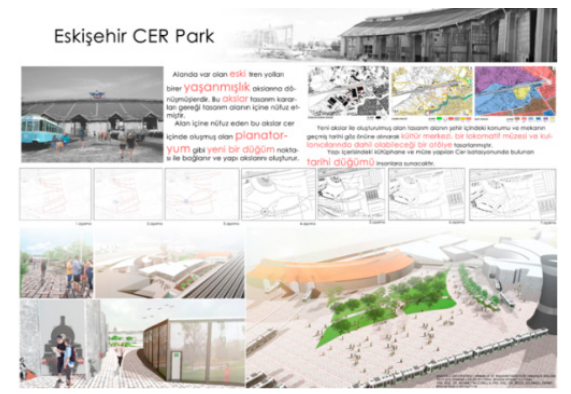

a

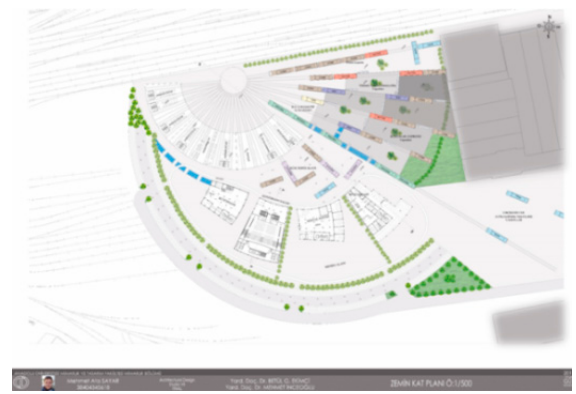

b
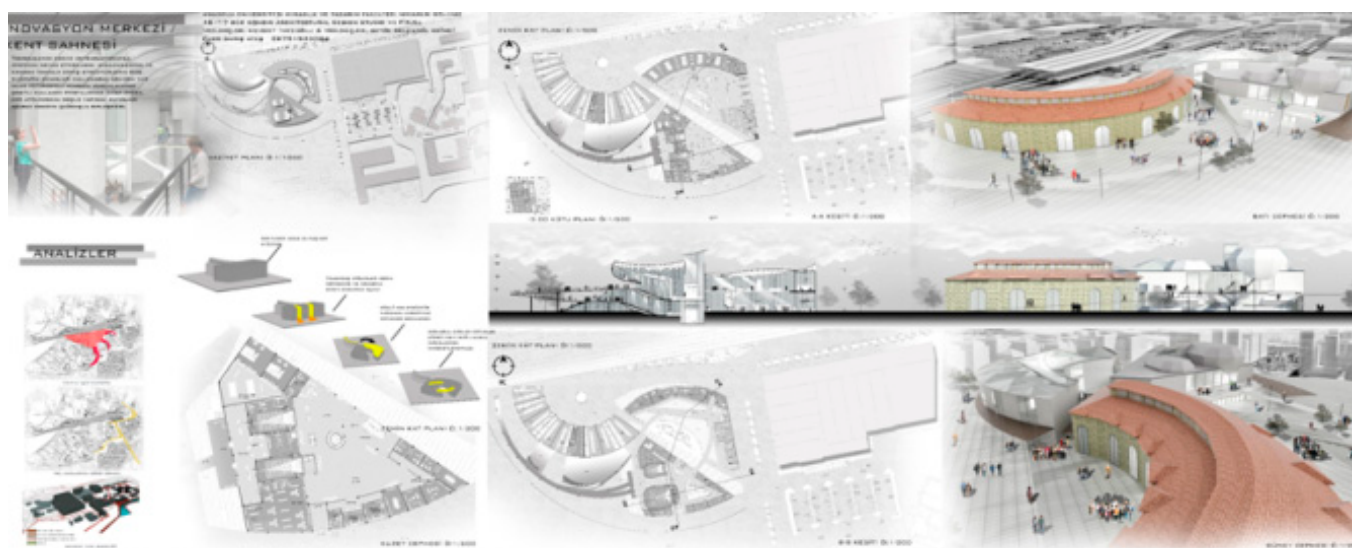

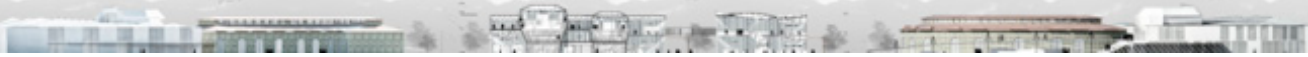

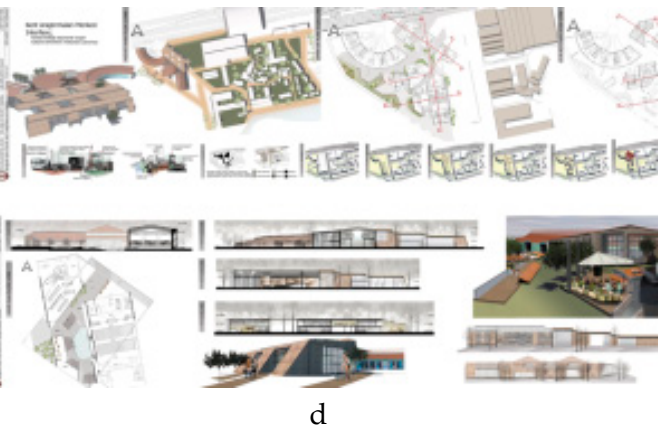

C

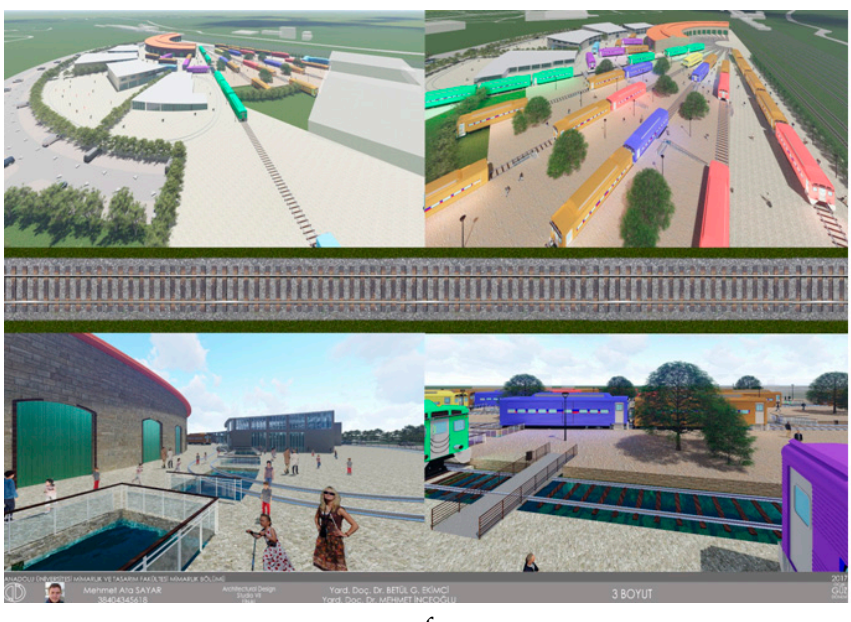

Figure 16. Students' proposals for the future of the Roundhouse Railway Workshop and its environment (a-f) Link of the photos augmented in dimension: https://mtf.eskisehir.edu.tr/sites/mtf.eskisehir.edu. tr/files/files/Figure16_link.pdf accessed on 16 January 2019. 
In the last section, intangible heritage research was developed through famous stories about train journeys. Students made these stories tangible in both tactile and visible terms through modeling and painting (Figure 17).

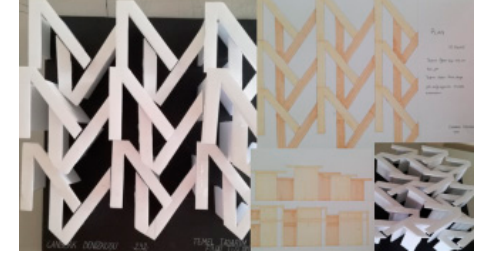

a

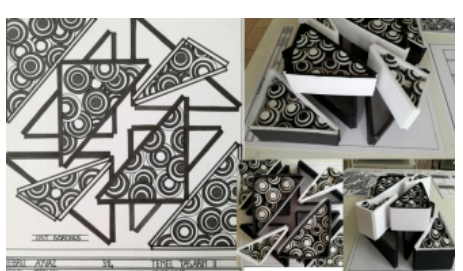

b

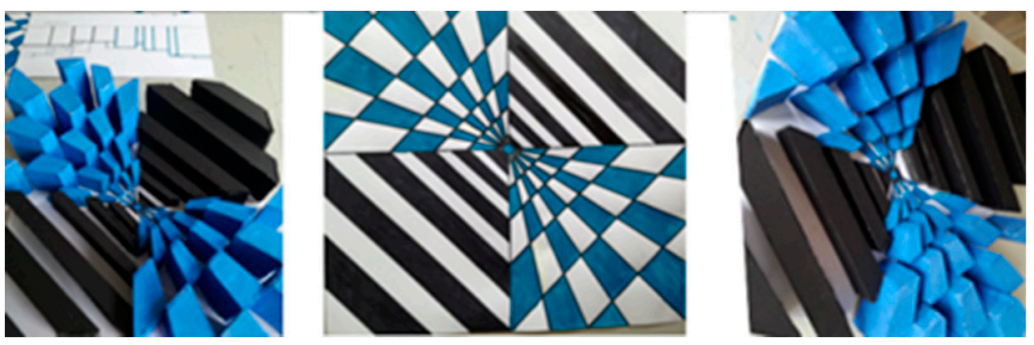

C

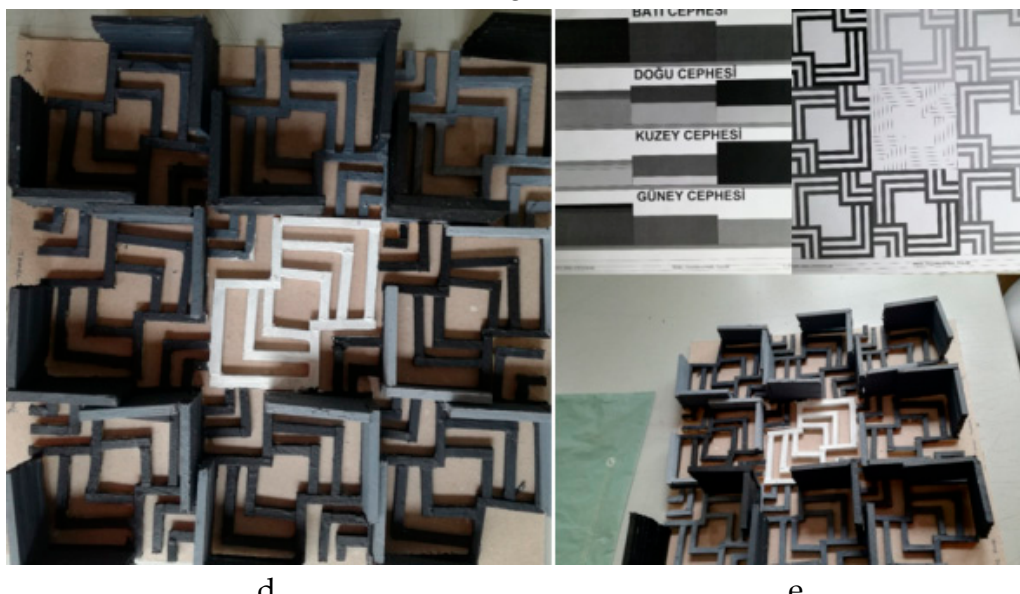

Figure 17. Models of basic design study: (a-e): description of the railway stories.

\section{Discussion}

This exhibition showcased the student involvement in history of Eskişehir and increased public awareness of cultural heritage. The exhibition paved the way for a dialogue between organizations and individuals who are concerned about the future of the derelict historical buildings located in the Central Station district of Eskişehir. Local authorities such as the Eskişehir Governorship Provincial Directorate of Culture, Ministry of Environment, District Municipality, and Turkish State Railways (TCDD) officials and employees attended the exhibition. In one day, more than 200 people came to visit a building that they previously never even knew existed. As in this case, sometimes we just need to reach out more to fill that gap. The news about the exhibition was published in the local press, and the exhibition continued to draw the attention of the public toward awareness for industrial heritage [15].

In this case study, we argue that the use of industrial heritage as a cultural resource entails a break with local actors and that it is important that industrial heritage is recognized as a part of the broad cultural inheritance of the city. The study also exposes the lack of localized and landscape approaches to the enhancement of industrial heritage. The heritage can function as a part of the city with the conception that considers it part of the cultural landscapes, with significant implications for spatial planning and for the conceptualization of industrial heritage. 


\section{Conclusions}

Resuscitation of the Railcar Repair Facility, even for a short time, as an exhibition venue brought back memories that are still vivid in people's minds and fostered several ideas to reclaim these buildings back in the city's daily life. It established a forum consisting of students, educators, and public to discuss the meaning and context of industrial heritage as an ongoing preservation issue with a real-life example. The discussions reiterated the importance of academic studies and symposiums to raise awareness on industrial heritage and to protect the significant buildings and sites that are under the threat of demolition.

Author Contributions: For research articles with several authors, a short paragraph specifying their individual contributions must be provided. The following statements should be used "Conceptualization, B.E.; Methodology, B.E., F.E., M.İ; Software, B.E.; Validation, B.E., F.E.; Formal Analysis, B.E., F.E.; Investigation, B.E., F.E., M.İ.; Resources, B.E., F.E., M.I.; Data Curation, B.E., F.E.; Writing-Original Draft Preparation, B.E., F.E.; Writing-Review \& Editing, B.E.; Visualization, B.E.; Supervision, B.E.; Project Administration, B.E.; Funding Acquisition, B.E., F.E., M.I.".

Funding: This research received no external funding.

Acknowledgments: A short video carried out by Sertan Bakar, Gamze Şensoy, and Sertan Bakar took part in the exhibition work. The authors would like to acknowledge and express their thanks for their invaluable contribution. Short video: https: / www.youtube.com/watch?v=w9hJ9xbE9gs, accessed on 16 January 2019.

Conflicts of Interest: The authors declare no conflict of interest. The funders had no role in the design of the study; in the collection, analyses, or interpretation of data; in the writing of the manuscript, and in the decision to publish the results.

\section{Appendix A}

Railroad buildings of Eskişehir: Challenges and Opportunities for Industrial Heritage Issues-paper accompanying this case study: http://www.arkitera.com/etkinlik/4641/eskisehirdemiryolu-binalari--endustri-mirasi-icin-zorluklar--firsatlar-anadolu-universitesi-mimarlik-vetasarim-fakultesi-mimarlik-bolumu-ogrenci-calismalari-.

\section{References}

1. TICCIH, The Nizhny Tagil Charter for the Industrial Heritage/July. 2003. Available online: https://www. icomos.org/18thapril/2006/nizhny-tagil-charter-e.pdf (accessed on 20 November 2018).

2. Joint ICOMOS-TICCIH Principles for the Conservation of Industrial Heritage Sites, Structures, Areas and Landscapes/November. 2011. Available online: http:/ / ticcih.org/about/about-ticcih/dublin-principles/ (accessed on 20 November 2018).

3. Riegl, A. The Modern Cult of Monuments: Its Character and Its Origin. In Oppositions-Selected Readings from A Journal for Ideas and Criticism in Architecture 1973-1984; Hays, K.M., Ed.; Forster, K.W.; Diane, G., Translators; Princeton Architectural Press: New York, NY, USA, 1998; pp. 621-651.

4. Riegl, A. Modern Anıt Kültü: Doğası ve Kökeni; Erdem, C., Translator; Daimond Publication: İstanbul, Turkey, 2005.

5. Immovable Cultural Presence Statistics Required to be Protected by Provinces. Available online: http://www. kulturvarliklari.gov.tr/TR,44799/illere-gore-korunmasi-gerekli-tasinmaz-kultur-varligi-i-.html (accessed on 14 November 2018).

6. Tülce, A.H. The Conservation Principles for the Brick and Tile Factories in Eskişehir. Master's Thesis, The Graduate School of Natural and Applied Sciences of Middle East Technical University, Ankara, Turkey, 2012.

7. Çayır, C. Conservation and Re-functioning of Industrial Heritage Eskisehir Factories Region Çift Kurt Tile and Brick Factory. Master's Thesis, Mimar Sinan Fine Arts University, Instıtute of Science, İstanbul, Turkey, 2011.

8. Eskişehir Development Plan. Eskişehir Büyükşehir Municipality. 2003. Available online: www.tepebasi.bel. tr/ (accessed on 14 November 2018). 
9. The Ministry of Culture and Tourism, the Law on the Conservation of Cultural and Natural Property, Property (2863), (14.07.2004-5226/9 art.). Available online: http:/ /www.kvmgm.gov.tr/belge/1-77085/ eski2yeni.html (accessed on 14 November 2018).

10. Espark Shopping Centre. Available online: http://gezginharitaci.blogspot.com/2013/04/espark-alisverismerkezi.html (accessed on 14 November 2018).

11. Oxitosin, Experiment on Trust. Available online: https://www.dasartproject.com/oksitosin-1 (accessed on 14 November 2018).

12. Corredor-Matheosy, Y.; Montaner, J.M. Arquitectura Industrial en Cataluña, de 1732 a 1929; Caja de Barcelona: Barcelona, Spain, 1984.

13. Sobrino, J. Arquitectura Industrial en España (1830-1990); Cátedra: Madrid, Spain, 1996.

14. Efe, A. Eskişehir Demiryolu. Master's Thesis, Social Sciences Institute, Anadolu University, Eskişehir, Turkey, 1998.

15. TCDD, Railway and Light Rail System News, News LIFE, “Eskisehir Railway Buildings: Challenges and Opportunities for Industrial Heritage" Exhibition Opened. Available online: https:/ / www.trenhaber.com/ yasam/eskisehir-demiryolu-binalar-endustriyel-miras-icin-zorluklar-h2451.html (accessed on 14 November 2018).

(C) 2019 by the authors. Licensee MDPI, Basel, Switzerland. This article is an open access article distributed under the terms and conditions of the Creative Commons Attribution (CC BY) license (http://creativecommons.org/licenses/by/4.0/). 